\title{
Correction: MicroRNAs and hepatitis $C$ virus: toward the end of miR-122 supremacy
}

Thomas W Hoffmann ${ }^{1,2}$, Gilles Duverlie ${ }^{1,2,3}$ and Abderrahmane Bengrine ${ }^{1,3^{*}}$

\section{Correction}

After publication of this work [1], we noted that two of the authors were incorrectly named. The author list for this article should read Thomas W Hoffmann, Gilles Duverlie and Abderrahmane Bengrine.

\section{Competing interest}

All authors declare that they have no competing interests.

\section{Authors' contributions}

TWH read the articles and gathered information cited in this review. GD revised the manuscript. TWH and AB drafted the manuscript. All authors read and approved the final manuscript.

\section{Author details}

${ }^{1}$ EA4294 Unité de Virologie Clinique et Fondamentale, Université de Picardie Jules Verne, UFR de Médecine et de Pharmacie, 3 rue des Louvels, 80036 Amiens Cedex, France. ${ }^{2}$ Laboratoire de Virologie, Centre Hospitalier Universitaire d'Amiens, Avenue René Laennec, 80480 Salouël, France. ${ }^{3}$ Biobanque de Picardie, Centre Hospitalier Universitaire d'Amiens, Avenue René Laennec, 80480 Salouël, France.

Received: 13 February 2013 Accepted: 13 February 2013 Published: 15 February 2013

\section{References}

1. Hoffmann et al: MicroRNAs and hepatitis $C$ virus: toward the end of miR-122 supremacy. Virology Journal 2012, 9:109.

\section{doi:10.1186/1743-422X-10-59}

Cite this article as: Hoffmann et al:: Correction: MicroRNAs and hepatitis $C$ virus: toward the end of miR-122 supremacy. Virology Journal 2013 10:59.

\footnotetext{
* Correspondence: abengrine@biobanque-picardie.com

'EA4294 Unité de Virologie Clinique et Fondamentale, Université de Picardie Jules Verne, UFR de Médecine et de Pharmacie, 3 rue des Louvels, 80036 Amiens Cedex, France

${ }^{3}$ Biobanque de Picardie, Centre Hospitalier Universitaire d'Amiens, Avenue René Laennec, 80480 Salouël, France

Full list of author information is available at the end of the article
}

\section{Submit your next manuscript to BioMed Central and take full advantage of:}

- Convenient online submission

- Thorough peer review

- No space constraints or color figure charges

- Immediate publication on acceptance

- Inclusion in PubMed, CAS, Scopus and Google Scholar

- Research which is freely available for redistribution

Submit your manuscript at

www.biomedcentral.com/submit

C BioMed Central

\section{Ciomed Central}

